\title{
Article
}

\section{The prevention of terrorism: in support of control orders, and beyond}

Turner, Ian David

Available at http://clok.uclan.ac.uk/4913/

Turner, Ian David ORCID: 0000-0002-8012-1480 (2011) The prevention of terrorism: in support of control orders, and beyond. Northern Ireland Legal Quarterly, 62 (3). pp. 335-359. ISSN 0029-3105

It is advisable to refer to the publisher's version if you intend to cite from the work.

For more information about UCLan's research in this area go to

http://www.uclan.ac.uk/researchgroups/ and search for < name of research Group>.

For information about Research generally at UCLan please go to

http://www.uclan.ac.uk/research/

All outputs in CLoK are protected by Intellectual Property Rights law, including Copyright law. Copyright, IPR and Moral Rights for the works on this site are retained by the individual authors and/or other copyright owners. Terms and conditions for use of this material are defined in the policies page.

\section{CLoK}

Central Lancashire online Knowledge www.clok.uclan.ac.uk

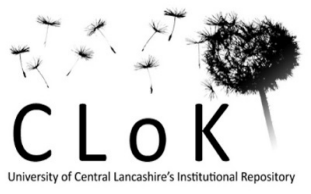




\title{
The prevention of terrorism: in support of control orders, and beyond
}

\author{
IAN TURNER* \\ University of Central Lancashire
}

\begin{abstract}
Introduction
$I^{2}$ nternational law dictates that the United Kingdom must fight terrorism. Article 3 of the Council of Europe's Convention on the Prevention of Terrorism, for example (which the UK has signed but not yet ratified), obliges states to prevent acts of terror and their negative effects. ${ }^{1}$ Similarly, the European Union's Counter Terrorism Strategy commits member states to combating terrorism globally so that their citizens can live in an area of freedom, security and justice. It is built around four strands: "prevent", preventing people from turning to terrorism; "protect", protecting citizens and critical infrastructure by reducing vulnerabilities; "pursue", pursuing and investigating terrorists, impeding planning, travel, and communications, cutting off funding and access to attack materials, and bringing terrorists to justice; and "respond", responding in a coordinated way by preparing to manage and minimise the consequences of a terrorist attack. ${ }^{2}$ These principles are reflected in the UK's strategy for combating terrorism, "Contest" (but domestically "respond" is replaced by the term "prepare"). ${ }^{3}$

One such measure that the UK has adopted to prevent individuals committing acts of terrorism, and therefore fulfilling its other international obligations in protecting its citizens and its infrastructure, as well as managing the risk posed by suspected terrorists, is the controversial control order scheme. But the international documents stated above do require states to respect fundamental rights and freedoms in their adoption of anti-terror initiatives. Indeed, a former Lord Chief Justice, Lord Woolf, has said that, although acts of

\footnotetext{
Senior lecturer in law, University of Central Lancashire. I am very grateful to an anonymous assessor for the comments provided on a previous draft of this article. The author is of course responsible for any errors or omissions. http://conventions.coe.int/Treaty/en/Treaties/Html/196.htm. pdf/en/05/st14/st14469-re04.en05.pdf. 20100418065544/http://www.homeoffice.gov.uk/documents/contest-leaflet2835.pdf?view=Binary, p. 4. But note, the UK government has recently published a new approach to "prevent" because of, for example, concern about the previous funding of extremist groups: HM Government, Prevent Strategy, CM 8092 June 2011 http://www.homeoffice.gov.uk/publications/counter-terrorism/prevent/prevent-strategy/preventstrategy-review?view $=$ Binary.
}

1 Council of Europe, Convention on the Prevention of Terrorism, 16 February 2005, Warsaw:

2 European Union, Counter Terrorism Strategy, 30 November 2005, Brussels: http://register.consilium.eu.int/

3 HM Government, Pursue, Prevent, Protect, Prepare, March 2009. http://webarchive.nationalarchives.gov.uk/
\end{abstract}


terrorism directed at a civil population are totally inconsistent with the values of human rights instruments such as the European Convention on Human Rights (ECHR), it is when the executive and the legislature dictate issues of national security that the protection of individual freedoms needs particular attention. ${ }^{4}$

Control orders are arguably one such initiative which unnecessarily infringe personal liberty: "[They] are corrosive of constitutionalism, since individual rights are diminished or eliminated without the convincing and legitimating public spectacle of a trial and proof beyond reasonable doubt." 5 They are, therefore, under attack from every quarter, it seems. For example, in July 2010 the Home Secretary, Theresa May, announced a review of the previous Labour government's many counter-terrorism measures, one of which was the control order scheme. ${ }^{6}$ She said that, over the past decade, the British state had become "too authoritarian" and the review was "an important first step in meeting our commitment to ... creating a counter-terrorism regime that is proportionate, focussed and transparent, striking the right balance between security and civil liberties". ${ }^{7}$

Control orders are seemingly unloved by human rights organisations, too. Amnesty International has recently described them as constituting a "shadow justice system", whereby a number of people have been accused by the authorities of involvement in terrorism-related activity, but have not been charged with any offence. The authorities have been relying on secret information in secret judicial hearings to keep those it deems a threat to national security under various forms of administrative control, amounting to a deprivation of liberty. ${ }^{8}$ Is it possible, therefore, for the author of this article to present a defensible argument justifying the continuation of the control order scheme? Should he, for his own credibility as an academic lawyer, who teaches a plethora of human rights modules across a range of undergraduate and postgraduate courses, even be trying to do so?

\section{UK strategies for preventing terrorism}

Before an attempt is made to defend the seemingly indefensible, it is important to discuss what exactly the author is proposing to support. Prior to the introduction of the control order scheme, the UK was permitted to detain indefinitely international terrorist suspects. Before it ceased to be law, s. 23 of the Anti-Terrorism, Crime and Security Act 2001 (ATCSA) had conferred such a power on the Home Secretary if, under s. 21(1), s/he reasonably believed that the international terrorist suspect's presence in the UK was a risk to national security, and s/he suspected that the detained person was a terrorist. ${ }^{9}$ Affected persons were able to appeal to the Special Immigration Appeals Commission (SIAC) if there were no reasonable grounds for detaining them, as per s. 25. Ordinarily the UK would have deported the foreign nationals to their countries of origin but Protocol 13 and Article 3 of the ECHR prohibited the authorities from doing so where there was a "real

4 Lord Woolf, "European Court of Human Rights on the occasion of the opening of the judicial year" (2003) EHRLR 257, pp. 260-1.

5 C Walker, Blackstone's Guide to the Anti-Terrorism Legislation 2nd edn (Oxford: OUP 2009), p. 212).

6 Home Office, Rapid Review of Counter-Terrorism Powers, 13 July 2010: www.homeoffice.gov.uk/mediacentre/press-releases/counter-powers.

7 Home Office, Taking Urgent Action to Restore Rights, 14 July 2010: www.homeoffice.gov.uk/mediacentre/news/taking-urgent-action.

8 Amnesty International, United Kingdom: Five years on: time to end the control orders regime, August 2010: www.amnesty.org.uk/uploads/documents/doc_20571.pdf, p. 4.

9 For criticisms of these previous anti-terror measures, see, for example: H Fenwick, "A proportionate response to 11 September?" (2002) 65 MLR 724; A Tomkins, "Legislating against terror" (2002) PL 205; and HRW, "Neither just nor effective", 24 June 2004 www.hrw.org/legacy/backgrounder/eca/uk/index.htm. 
risk" of either death or torture, as per Chabal v United Kingdom..$^{10}$ Death or torture was certainly likely where an individual had been labelled as an "international terror suspect" by the British government (though now the UK might be permitted to return detainees to countries such as Jordan, Algeria, Lebanon, Libya and Ethiopia where "diplomatic assurances" or "memoranda of understanding" are in place to prevent receiving countries from harming deportees). In order to justify the ATCSA provisions, the UK had to derogate from Article 5 of the ECHR, the right to liberty, by virtue of Article 15(1) of the ECHR ("derogation in time of emergency").

In $A \mathrm{v}$ Secretary of State for the Home Department, ${ }^{11}$ the challenge to the indefinite detention measures was heard by the then House of Lords (now Supreme Court) in October 2004. By a majority of $8: 1$, the judges agreed with the UK authorities that the threat from international terrorism post-9/11 had been a public emergency threatening the life of the nation for the purposes of Article 15(1). But the state's response - the Part IV provisions of ATCSA - was not proportionate to the public emergency as it had not been "strictly required by the exigencies of the situation". They therefore quashed the Human Rights Act (Designated Derogation) Order 2001, permitting the derogation in domestic law, and held that the legislation was "incompatible" with Article 5, as per s. 4 of the Human Rights Act 1998 (HRA). Lord Hoffman said:

The real threat to the life of the nation, in the sense of a people living in accordance with its traditional laws and political values, comes not from terrorism but from laws such as these. ${ }^{12}$

His Lordship (who was in a minority on this issue) even went as far as suggesting that there had not been a war or public emergency threatening the life of the nation which had justified the derogation under Article 15(1). ${ }^{13}$ The House of Lords also ruled that the ATCSA measures had been a disproportionate interference with Article 14 of the ECHR, the prohibition on the discrimination of convention rights, in that the executive detention provisions were applicable only to foreign nationals, not British suspects (this not having been the subject of an original derogation under Article 15(1)). The ruling of the House of Lords has received significant academic praise. For example, one commentator has described it as "perhaps the most powerful judicial defence of liberty since [the 1770s]". ${ }^{14}$

For several reasons the Law Lords doubted the rationality of the indefinite detention measures: for example, no state other than the UK had derogated from Article 5, even though other European countries such as France, Italy and Germany were at risk from international terrorism; ${ }^{15}$ the legislation, in targeting only foreigners suspected of threatening the security of the UK, seemed to rule out an attack from British jihadists (which was tragically proven to be incorrect with the terror attacks in London on the 7 July 2005 when four British Muslim men detonated suicide vests on the London transport

10 (1996) 23 EHRR 413.

11 [2004] UKHL 56, [2005] 2 AC 68.

12 Ibid. para, 97.

13 Ibid. para. 96.

14 D Feldman, "Proportionality and discrimination in anti-terrorism legislation" (2005) 64 CLJ 271, p. 273. See also: T Hickman, "Between human rights and the rule of law: indefinite detention and the derogation model of constitutionalism" (2005) 68 MLR 655; A Tomkins, "Readings of A v Secretary of State for the Home Department" (2005) PL 259; and D Dwyer, "Rights brought home" (2005) 121 LQR 359.

15 [2004] UKHL 56, [2005] 2 AC 68, at para. 20. 
network, killing 52 people and injuring over $700^{16}$ - see more later); $;^{17}$ and releasing the detainees, if they left the UK, obviously overlooked the possibility of them pursuing their terrorist objectives abroad. ${ }^{18}$

The declaration of incompatibility issued by the House of Lords in $A$, in common with all such declarations, was not binding on the parties to the application, as per s. 4 of the HRA. The applicants therefore remained in detention, except for the second and fourth applicants who elected to leave the UK, and the fifth applicant who was released on bail on conditions amounting to house arrest. Also, none of the applicants were entitled to compensation in respect of their unlawful detention. In this regard, they lodged complaints with the European Court of Human Rights (ECtHR): A v United Kingdom. ${ }^{19}$ The ECtHR came to a similar conclusion to the House of Lords: the UK was entitled to conclude that the threat from international terrorism had constituted a "public emergency" for the purposes of Article 15(1) of the ECHR. But the ATCSA measures were not "strictly required by the exigencies of the situation" to warrant a derogation from Article 5. The applicants were therefore entitled to compensation ("just satisfaction" as per Article 41 of the ECHR) for a breach of their liberty. (The significance of the ECtHR's ruling in $A$ in reference to the legality of evidence relied on by the state is discussed later.)

Following the ruling of the House of Lords in $A$, the government allowed ATCSA to lapse in March 2005 (the legislation had had a sunset clause, requiring it to be renewed, otherwise it would cease). It replaced ATCSA with the Prevention of Terrorism Act 2005 (PTA), introducing control orders. These can be imposed on all terror suspects, whether they are British or foreign. According to s. 1(1) of the PTA a control order is an order against an individual which imposes obligations on him or her for purposes connected with protecting members of the public from a risk of terrorism. Section 1(4) of the PTA states that these obligations may include, for example, (d) a restriction on a person's association or communications with specified persons; (e) a restriction in respect of a person's place of residence; $(\mathrm{f})$ a prohibition on a person being at specified places or within a specified area at specified times or on specified days; or (p) a requirement on a person to report to a specified individual at specified times and places during the day. Section 1(4) therefore permits the state to impose obligations on individuals which include, for example, electronic tagging, curfews, restrictions on visitors and meeting others, a ban on the use of the internet and limits on phone communication. The Home Office has stated that conditions imposed under a control order are "tailored to each case to ensure the person cannot take part in terrorist activity". ${ }^{20}$ As of June 2011, there were 12 control orders in force, all of which were in respect of British citizens. Three individuals subject to a control order live in the Metropolitan Police Service area; the remaining individuals live in other police force areas. ${ }^{21}$

16 BBC News, “London attacks", 8 July 2005: http://news.bbc.co.uk/1/hi/in_depth/uk/2005/ london_explosions/default.stm.

17 [2004] UKHL 56, [2005] 2 AC 68, para. 30.

18 Ibid. para. 34. In this regard the ruling was perhaps unsurprising, as Starmer argues: K Starmer, "Setting the record straight: human rights in an era of international terrorism" (2007) EHRLR 123, p. 124: "Against this background it can hardly be suggested that their Lordships were mischievously dismantling the Government's anti-terrorism strategy. They were simply pointing out that the Government's approach was discriminatory, irrational and, worst of all, ineffective."

19 (2009) 49 EHRR 29.

20 Home Office, "The facts about control orders": www.homeoffice.gov.uk/security/terrorism-and-thelaw/control-orders $/$ ?version $=4 \#$.

21 Home Office, "Written ministerial statement on control orders", 11 March-10 June 2011: http://services.parliament.uk/hansard/commons/bydate/20110616/writtenministerialstatements/part006.html. 
Section 2(1) of the PTA allows the Secretary of State to make a control order against an individual if the Secretary of State (a) has reasonable grounds for suspecting that the individual is or has been involved in terrorism-related activity; and (b) considers that it is necessary for purposes connected with protecting members of the public from a risk of terrorism. A control order made by the Secretary of State is called a "non-derogating" control order (s. 2(3)) and is valid for a period of 12 months, but may be renewed on one or more occasions (s. 2(4)).

Section 3 of the PTA concerns the judicial supervision of the making of a nonderogating control order. The Secretary of State cannot impose a non-derogating control order except where s/he has been granted permission by a court (though s. 3(1)(b) does permit the granting of a control order where the urgency of the case requires the order to be made without permission but there must be a court hearing within seven days (s. 3(4)). The function of the judicial supervision at this stage (without the participation or knowledge of the person who will be affected) is to consider whether the Secretary of State's decision to make an order is "obviously flawed" (s. 3(2)(b)). The minister's decision is also subject to a subsequent more substantive review by the High Court, with some participation by the affected person. That is, following the granting of permission by the court, there must be a court hearing judicially reviewing the control order and its conditions "as soon as reasonably practicable after it is made" (s. 3(10)).

The PTA also allows for the provision of "derogating" control orders (from Article 5 of the ECHR, the right to liberty, for example), which are tantamount to house arrest. These orders can be issued only by the High Court under s. 4 and the rules for their issue are stricter than those for non-derogating control orders. There are currently no derogating control orders in operation. ${ }^{22}$

\section{Control orders, human rights and the courts}

Before seeking to defend the control order scheme, the author will outline the human rights implications of some of the orders that have previously been issued and the courts' responses to the lawfulness of these orders. In most cases, they will be addressed again later when support for the measures is presented.

\section{ARTICLE 5 OF THE ECHR: THE RIGHT TO LIBERTY}

Very soon after the introduction of the control order scheme the parliamentary Joint Committee on Human Rights (JCHR) expressed the opinion that the measures were not, per se, contrary to human rights such as Article 5 of the ECHR, the right to liberty. ${ }^{23}$ But concern was raised about the combination of obligations imposed on a controlee which were capable of constituting a deprivation of liberty. ${ }^{24}$

The House of Lords in Secretary of State for the Home Department $\mathrm{v} J J^{25}$ came to the same conclusion as the JCHR about the general lawfulness of the control order measures. Nevertheless, individual obligations imposed on a controlee certainly were the subject of judicial censure. In $J J$, the conditions depriving the liberty of the six applicants included: residency at a one-bedroom flat, away from one's normal home, for 18 hours per day (from 16.00 to 10.00); electronic tagging; compulsory attendance at a police station twice a day;

22 Home Office, "Written ministerial statement", n. 21 above.

23 JCHR, Counter-Terrorism Policy and Human Rights: Draft Prevention of Terrorism Act 2005 (Continuance in force of sections 1 to 9) Order 2006 (12th report of session 2005-06), 2006, para. 36.

24 Ibid., at para. 37.

25 [2007] UKHL 45, [2008] 1 AC 385. 
visitors to have been approved by the Home Office; limited use of the telephone; and a ban on the use of the internet. Adopting the test of the ECtHR in Gurzardi v Italy, ${ }^{26}$ Lord Bingham said that a deprivation of liberty may take numerous forms other than classic detention in prison or strict arrest. ${ }^{27}$ What had to be considered was the concrete situation of the particular individual. Account should be taken of a whole range of factors such as the nature, duration, effects and manner of execution or implementation of the penalty or measure in question. ${ }^{28}$ Thus, the House of Lords found (by a 3:2 majority) that the specific non-derogating control orders imposed on the controlee applicants were unlawful. Lord Bingham likened the conditions to prison but without the benefit of association with others. ${ }^{29}$

Notwithstanding the House of Lords in JJ quashing some non-derogating control orders for deprivations of liberty, the JCHR in 2008 continued to express reservations about the control order scheme itself: "We remain concerned that the regime as it currently stands and as it is currently operated is very likely to result in breaches of . . . the right to liberty." 30 This belief was reiterated in the JCHR's 2009 report on control orders. ${ }^{31}$ Assuming therefore that control orders are, in general, infringements of liberty, it is also important to note that controlees' liberty is being deprived without them having been found guilty of an offence. ${ }^{32}$ This is outlawed by Article 5(1)(c) of the ECHR.

\section{ARTICLE 6 OF THE ECHR: THE RIGHT TO A FAIR AND PUBLIC TRIAL BY AN INDEPENDENT AND UNBIASED TRIBUNAL}

Concern has also been expressed by organisations such as the JCHR about the lack of fairtrial protections with the control order scheme. ${ }^{33}$ Article 6(1) of the ECHR entitles a person to a fair and public trial by an independent and unbiased tribunal. Those subject to criminal charges are afforded further protection. Article 6(2) states that everyone charged with a criminal offence shall be presumed innocent until proved guilty according to law; Article 6(3) states that everyone charged with a criminal offence has the minimum rights such as "(a) to be informed promptly, in a language which he understands and in detail, of the nature and cause of the accusation against him" and "(d) to examine . . . witnesses against him". However, control order proceedings are not classified in domestic law as "criminal" in nature. They are intended to be civil orders, used as alternatives to criminal prosecution in cases where prosecution is not possible because of a lack of evidence. There are therefore fewer procedural guarantees given to controlees than those accorded to suspects charged with an "ordinary" crime. In 2006, the JCHR argued that control orders were more than mere civil orders. First, the conduct which was alleged, being the basis for the control order, was not only conduct of a criminal nature, but of a particularly serious criminal nature - involvement in terrorism-related activity. Secondly, the nature of the

26 (1980) 3 EHRR 533.

27 [2007] UKHL 45, [2008] 1 AC 385, para. 15.

28 Ibid. para. 16.

29 Ibid. para. 24. But doubt does still remain about the practical application of the law following $J J$ - see, for example, D Feldman, "Deprivation of liberty in anti-terrorism law" (2008) 67 CLJ 4, p. 7.

30 JCHR, Counter-Terrorism Policy and Human Rights (9th report): Annual Renewal of Control Orders Legislation 2008 (10th report of session 2007-08), 2008, para. 88.

31 JCHR, Counter-Terrorism Policy and Human Rights (14th report): Annual Renewal of Control Orders Legislation 2009 (5th report of session 2008-09), 2009, para. 33.

32 K Ewing and J Tham, "The continuing futility of the Human Rights Act" (2008) PL 668, p. 669. The thesis of Ewing and Tham's article is the general weakness of the HRA in protecting fundamental freedoms, especially post-9/11. But see the criticisms of Ewing and Tham's thesis: A Kavanagh, "Judging the judges under the Human Rights Act: deference, disillusionment and the 'war on terror"' (2009) PL 287.

33 JCHR 2006, n. 23 above. 
restrictions imposed were of a nature and severity to be equivalent to a criminal penalty. Thirdly, they were also of a duration to make them tantamount to a criminal sanction, being, in effect, indefinitely renewable. ${ }^{34}$ Human rights organisations such as Amnesty International $^{35}$ and Human Rights Watch (HRW) have criticised the civil nature of control orders for these reasons, too. HRW has also remarked that a breach of a control order is a criminal offence punishable by up to five years' imprisonment and/or a fine. ${ }^{36}$ In addition, the standard of proof for the issuing of a control order - reasonable suspicion - is far lower than the criminal standard of proof - beyond a reasonable doubt - and indeed is lower than the civil threshold - a balance of probabilities. This means controlees are potentially being deprived of their liberty on the basis of a very low standard of proof $-\mathrm{a}$ balance very much in the state's favour. ${ }^{37}$

Furthermore, concern about the lack of procedural safeguards with the control order scheme is directed at the court proceedings. The control order process (very much like that for SIAC, see earlier) uses a system of dual hearings and legal representation. Each person is assigned a security-cleared barrister known as a "special advocate". Classified information and evidence is heard during "closed" sessions attended by the special advocate. Suspects and their lawyers of choice are excluded from those sessions, and contact between the special advocates and the suspects is prohibited once special advocates have been privy to the closed material. Non-classified evidence is heard at "open" hearings with the suspect present. Thus, suspects are being denied a public forum where they are able to confront their accusers if the state's reliance on evidence supporting the control order is presented in a closed session. ${ }^{38}$ Moreover, the special advocates' inability to communicate with affected persons after seeing the closed material arguably seriously limits their ability to represent the interests of the controlled persons and therefore the extent to which they can mitigate the alleged unfairness in the closed sessions. ${ }^{39}$

In Secretary of State for the Home Department $\mathrm{v} M B, A F,{ }^{40}$ the House of Lords held that Article 6(1) of the ECHR does apply to control order proceedings, ${ }^{41}$ but Articles 6(2) and 6(3) do not. ${ }^{42}$ However, Lord Bingham did say that in any case in which a person was at risk of a control order containing obligations of the stringency found in this case (AF was subject to a 14-hour daily curfew, for example) the application of the civil limb of Article 6 of the ECHR - Article 6(1) - did entitle such a person to a "measure of procedural protection as is commensurate with the gravity of the potential consequences". 43 So the House of Lords concluded that there would be some cases where the failure to disclose evidence to the controlled person would be incompatible with the requirements of a fair trial.

The evidence against MB, for example, was one such case where there was great reliance by the state on closed material; the open case before him containing no more than a bare

34 JCHR 2006, n. 23 above, paras 50-1.

35 Amnesty International, United Kingdom: Five years on, n. 8 above, pp. 5-6.

36 HRW, Putting Human Rights at the Center of United Kingdom Counterterrorism Policy, June 2007: www.hrw.org/ legacy/backgrounder/eca/uk0607/uk0607web.pdf, p. 18.

37 See, for example, A Tomkins, "National security and the role of the court: a changed landscape" (2010) 126 LQR 543, pp. 557-8.

38 Ewing and Tham, "The continuing futility", n. 32 above, p. 669.

39 JCHR 2010, Counter-Terrorism Policy and Human Rights (16th Report): Annual Renewal of Control Orders Legislation 2010 (9th Report of Session 2009-10), 2010: www.publications.parliament.uk/pa/ jt200910/jtselect/jtrights/64/6402.htm, para. 72 .

40 [2007] UKHL 46, [2008] 1 AC 440.

41 Ibid. para. 24.

42 Ibid.

43 Ibid. 
assertion of liability. In the case of $A F$ the open case for a control order was also very limited; the essence of the case against him was in the closed material. On the facts of the case, the House of Lords found that the control proceedings involving MB and AF had not been Article 6(1) compliant. Nevertheless, academic commentators have argued that the principles from $M B, A F$ - how much closed material, if any at all, should be disclosed for the purposes of fair-trial compliance? - was dealt with insufficiently by the House of Lords, especially as it left open the possibility of compatibility even where the state had relied solely on closed evidence. ${ }^{44}$

Greater respect for the fair-trial rights of those subject to, for example, a control order was provided by the ECtHR in $A \mathrm{v}$ United Kingdom, ${ }^{45}$ when it considered the lawfulness of the previous indefinite detention provisions under ATCSA. The applicants alleged inter alia that the special advocate procedure before SIAC had not complied with Article 5(4) of the ECHR: a person's detention should be decided speedily by a court. On this issue, the ECtHR said:

The special advocate could not perform [their] function in any useful way unless the detainee had been provided with sufficient information about the allegations against him to enable him to give effective instructions to the special advocate. ${ }^{46}$

So the ECtHR expressed doubt about the general fairness of the special advocate process. In Secretary of State for the Home Department $\mathrm{v} A F,{ }^{47}$ the House of Lords followed the ruling of the ECtHR in $A$, and, arguably, overruled its earlier decision in $M B, A F$, where it had suggested that state reliance on closed material could be compatible with Article 6(1). The court said that non-disclosure on the ground of national security of relevant material could not go so far as to deny a party knowledge of the essence of the case against them, at least where they were at risk of consequences as severe as those normally imposed under a control order. Provided that that requirement was satisfied, there could be a fair trial notwithstanding that a controlled person was not provided with the detail or the sources of the evidence forming the basis of the allegations. ${ }^{48}$

The consequence of this ruling of the House of Lords is significant: a controlee must be made aware of the nature of the allegations against them (but not necessarily the evidence supporting the allegations). The state must therefore either release more information to the suspect or revoke the control order (or issue a derogating control order as per s. 4 of the PTA?). ${ }^{49}$ (In some cases, rather than subsequently revoking a control order because the state has failed to publish relevant evidence against a controlee, ${ }^{50}$ the courts have quashed an order, thus permitting the controlee the opportunity to sue for damages. $)^{51}$

44 E.g. C Forsyth, "Control orders, conditions precedent and compliance with Article 6(1)" (2008) 67 CLJ 1, p. 4.

45 (2009) 49 EHRR 29.

46 Ibid. para. 220.

47 [2009] UKHL 28, [2009] 3 WLR 74.

48 Ibid. para. 59.

49 The state's action (or inaction) following $A F$ has been ridiculed: "[The] Home Office engages in a teasing dance, involving the shedding of intelligence veils from its dossier. The dance is sometimes embarrassing, as when further information has to be revealed, and occasionally impossible, as when the Home Office declines the demand for further disclosure and drops the case.": C Walker, "The threat of terrorism and the fate of control orders" (2010) PL 4, p. 5.

50 Following the ruling of the House of Lords in $A F$, the High Court in Secretary of State for the Home Department $\mathrm{v} A N$ and Another (proceedings under the Prevention of Terrorism Act 2005) [2009] EWHC 1966 (Admin), for example, revoked the control order since no evidence against the applicant, AN, had been disclosed by the authorities.

51 E.g. Secretary of State for the Home Department $\mathrm{v} A E$ and AF [2010] EWCA Civ 869. 
However, notwithstanding the seemingly positive outcome from the ruling of the House of Lords in AF, the JCHR still remains sceptical about the basic fairness of control order proceedings, especially involving those where the state's reliance on material is largely dependent on closed evidence:

We heard from the special advocates that, although the Government had said that it would be reviewing the material in each case in the light of AF to see whether further disclosure could be made or whether the control order should be revoked, in practice the Secretary of State has taken a "minimalist" and essentially passive approach ... not voluntarily disclosing any more material but leaving it to the special advocates to make the running on what more should be disclosed and waiting for the courts to tell the Secretary of State what material he cannot rely on unless he discloses it. ${ }^{52}$

\section{ARTICLE 3 OF THE ECHR: THE PROHIBITION ON TORTURE AND INHUMAN AND DEGRADING TREATMENT AND PUNISHMENT}

There is also concern that the control order scheme, or individual obligations imposed on a controlee, might contravene Article 3 of the ECHR, the prohibition on torture and inhuman and degrading treatment and punishment. For example, many of the former detainees under ATCSA were said to have suffered from depression and suicidal thoughts. To this end, detainee $G$ was granted bail after SIAC accepted that his detention had triggered "psychotic episodes".53 In 2005, the European Committee for the Prevention of Torture (CPT) reported on its visit to the UK during 2004. In reference to some of the ATCSA detainees, it stated:

Two years after the CPT visited these detained persons, many of them were in a poor mental state as a result of their detention, and some were also in poor physical condition. Detention had caused mental disorders in the majority of persons detained under the ATCSA and for those who had been subjected to traumatic experiences or even torture in the past, it had clearly reawakened the experience and even led to the serious recurrence of former disorders. The trauma of detention had become even more detrimental to their health since it was combined with an absence of control resulting from the indefinite character of their detention, the uphill difficulty of challenging their detention and the fact of not knowing what evidence was being used against them to certify and/or uphold their certification as persons suspected of international terrorism. For some of them, their situation at the time of the visit could be considered as amounting to inhuman and degrading treatment. ${ }^{54}$

In 2006, the CPT reported on its visit to the UK during 2005. It was able to interview some individuals subject to control orders. In reference to one individual, P, the CPT stated that he was severely depressed and anxious, in considerable distress and despair, with symptoms of post-traumatic stress disorder. It noted that the depression could not be treated as long as the control order restrictions remained in place. So the risks of self-harm and even suicide were significant. ${ }^{55}$

52 JCHR 2010, n. 39 above, para. 50.

$53 G \mathrm{v}$ Secretary of State for the Home Department [2004] EWCA Civ 265, [2004] 1 WLR 1349.

54 CPT, Report to the Government of the United Kingdom on the Visit to the United Kingdom Carried out by the European Committee for the Prevention of Torture and Inbuman or Degrading Treatment or Punishment (CPT) from 14 to 19 March 2004, 9 June 2005: www.cpt.coe.int/documents/gbr/2005-10-inf-eng.pdf, para. 19.

55 CPT, Report to the Government of the United Kingdom on the Visit to the United Kingdom Carried out by the European Committee for the Prevention of Torture and Inhuman or Degrading Treatment or Punishment (CPT) from 20 to 25 November 2005, 10 August 2006: www.cpt.coe.int/documents/gbr/2006-28-inf-eng.pdf, para. 46. 
Is it not the case, therefore, that not knowing exactly what one has allegedly done wrong to justify a control order, and sometimes not being able to test the evidence in open court supporting the state's suspicion, possibly causes untold stress and anxiety? Moreover, is this not also compounded by the fact that a control order is imposed without any term (though it must be renewed annually)?

\section{ARTICLE 8 OF THE ECHR: THE RIGHT TO PRIVATE AND FAMILY LIFE, HOME AND CORRESPONDENCE}

In 2006 the JCHR expressed concern that control orders were "unjustifiably interfering with the human rights of other members of the [controlee's] family". 56 Of particular concern to the JCHR over the currency of the scheme has been the condition requiring a controlee to move away from their normal place of residence, often away from their family and friends. ${ }^{57}$ The effects of a control order on a controlee's family and friends has not been lost on the Supreme Court. In earlier House of Lords' rulings, the duration of a control order in terms of curfew hours seemed to be the determining factor (despite Lord Brown and others rejecting Lord Hoffman's opinion in $J J$ that a deprivation of liberty should be confined to actual imprisonment or something little different from imprisonment). ${ }^{58}$ But not so in Secretary of State for the Home Department v AP. ${ }^{59}$

Here the applicant, AP, was confined to a place of residence for 16 hours per day. However, he was living in the Midlands, 200 miles away from the rest of his family in London. The court said that the rights of the applicant under Article 8(1) of the ECHR, the right to respect for private and family life, home and correspondence, were proportionately infringed for the purposes of protecting national security, as per Article 8(2). However, a residency obligation could still affect the lawfulness of a control order. On the facts, the court found that the requirement to live in the Midlands was unlawful, albeit a deprivation of liberty as per Article 5 of the ECHR. So, in practice, this was a denial of liberty but the Article 8(1) right of the applicant, which ordinarily was proportionately infringed, did affect, to some considerable degree, the legality of the control order under Article 5.60 Interestingly, in Secretary of State for the Home Department $\mathrm{v}$ $A P$ (No 2), ${ }^{61}$ AP was granted anonymity because to do otherwise could risk violating his rights under Article 3 of the ECHR. The town where he had to live was one where there were considerable community tensions. There was organised racist activity and there had been racist attacks, including physical violence, on members of the Muslim community. ${ }^{62}$

The obligation to move 200 miles away from one's family and friends was obviously a condition too far for the Supreme Court in $A P$. But would a residency requirement closer to home have been lawful? This issue still troubles the JCHR. In its 2010 report, the JCHR noted:

We heard with alarm about the "growing use" of conditions ... which require the controlled person to move out of the community in which they live and stay away from it - "a form of internal exile" ... We learned that these "relocation conditions" are being used to require British citizens who have grown up in a particular community to uproot themselves from that community and move to a

56 JCHR 2006, n. 23 above, para. 85.

57 JCHR 2010, n. 39 above, para. 72.

58 [2007] UKHL 45, [2008] 1 AC 385, para. 44.

59 [2010] UKSC 24, [2010] 3 WLR 51.

60 On this issue, see also, for example, CA v Secretary of State for the Home Department [2010] EWHC 2278 (Admin).

61 [2010] UKSC 26, [2010] 3 WLR 51.

62 Ibid. para. 13. 
new and unfamiliar location. The impact of such relocations on the controlled person's families was described as "extraordinary". The female partners of controlees, we heard, "are treated with complete contempt", told that they can either stay where they are or move to the new location and find a new job. Children are uprooted from the schools they have been attending and forced to relocate in order to be with their family. ${ }^{63}$

\section{OTHER ARGUMENTS AGAINST CONTROL ORDERS}

In addition to the seemingly unjustified infringements of human rights that the control order scheme continues to cause some controlees, the JCHR has also expressed concern about the financial cost of the scheme. It says that control orders have been the most litigated of the government's counter-terrorism measures since 2001, and "quite probably the most litigated ever". 64 It concludes by questioning whether the cost of maintaining the system is out of all proportion to the public benefit which the orders are said to serve. ${ }^{65}$ Notwithstanding the financial cost of the scheme a view shared by the human rights organisation Liberty, Liberty also notes the "absurd" proportion of controlees who have absconded over the years. ${ }^{66}$

In summary, the UK's control order scheme, replacing the discredited indefinite detention provisions for international terror suspects under ATCSA, has been the subject of significant criticism since its inception. In 2007, the JCHR believed that the measure's infringements of human rights required, for example, derogation from Articles 5 and 6 of the ECHR, as per Article 15(1). ${ }^{67}$ In its 2009 report on control orders, the JCHR, largely accepting of the then government's intended retention of the scheme, sought to further restrict the effect on controlees and their families by calling for a maximum duration imposed on control orders. ${ }^{68}$ But in 2010, although acknowledging that in the past it had had an open mind about the scheme, ${ }^{69}$ the JCHR had had enough:

The continued operation of the ... system has . . led to more unfairness in practice, more unjustifiable interferences with people's liberty, more harm to people's mental health and to the lives of their families, even longer periods under indefinite restrictions for some individuals ... more protracted litigation to which there is no end in sight, more claims for compensation, ever-mounting costs to the public purse, and untold damage to the UK's international reputation as a nation which prizes the value of fairness. For a combination of these reasons, together with serious reservations about the practical value of control orders in disrupting terrorism compared to other means of achieving the same end, we have reached the clear view that the system of control orders is no longer sustainable. ${ }^{70}$

The apparent curtailment of basic liberties - at considerable public financial cost, it appears - seemingly do not justify (at the very least) the control order scheme in its present

63 JCHR 2010, n. 39 above, para. 72.

64 Ibid. para. 99.

65 Ibid. para. 106.

66 Liberty, From 'War" to Law: Liberty's response to the Coalition government's review of counter-terrorism and security powers, August 2010: www.liberty-human-rights.org.uk/pdfs/policy10/from-war-to-law-final-pdf-with-bookmarks.pdf.

67 JCHR, Counter-Terrorism Policy and Human Rights: Draft Prevention of Terrorism Act 2005 (Continuance in force of sections 1 to 9) Order 2007 (8th Report of Session 2006-07), 2007 www.publications.parliament.uk/ pa/jt200607/jtselect/jtrights/60/6002.htmat, para. 63.

68 JCHR 2009, n. 31 above, para. 2.

69 JCHR 2010, n. 39 above, para. 90.

70 Ibid. paras 111-12. 
form. The JCHR has now come out in favour of the scheme's complete abolition. A view shared by human rights organisations such as Amnesty International ${ }^{71}$ and Liberty. ${ }^{72}$

\section{Arguments in support of control orders}

The author's principal support for the control order scheme is public protection - the overriding right of individuals to be free from terrorist violence. Before exploring this argument in more detail, some perhaps "less important" points defending control orders need to be noted. First, the author will address the human rights implications of control orders for those individuals subject to them, beginning with Article 5 of the ECHR, the right to liberty.

\section{ARTICLE 5 OF THE ECHR: THE RIGHT TO LIBERTY}

Earlier it was argued that controlees are being deprived of their liberty, in cases where they have not been convicted of an offence. But, importantly, the House of Lords has accepted that some control order obligations do not infringe Article 5 of the ECHR: Secretary of State for the Home Department v $M B, A F^{73}$ (AF's 14-hour daily curfew, MB was not subject to a curfew) and Secretary of State for the Home Department $\mathrm{v} E^{74}$ (E's 12-hour daily curfew). In Secretary of State for the Home Department $\mathrm{v} J J{ }^{75}$ Lord Brown offered guidance as to where the boundaries of Article 5 of the ECHR and non-derogating control orders lay:

$[\mathrm{T}]$ aking account of . . . all these various control order cases, provided the "core element of confinement" does not exceed sixteen hours a day, it is "insufficiently stringent" as a matter of law to effect a deprivation of liberty. ${ }^{76}$

For some, restrictions on a person's movement for up to 16 hours a day is an encroachment on individual freedom. However, the effect of these judicial rulings is significant: for the purposes of combating terrorism, such obligations are not denials of liberty to the degree that they are outlawed by the ECHR.

\section{ARTICLE 6 OF THE ECHR: THE RIGHT TO A FAIR AND PUBLIC TRIAL BY AN INDEPENDENT AND UNBIASED TRIBUNAL}

Concern was expressed previously about the "civil" nature of control orders, thus the "criminal" safeguards permitted by Articles 6(2) and (3) of the ECHR are excluded. But this issue has been examined and approved by the House of Lords. In Secretary of State for the Home Department v $M B, A F, 77$ Lord Bingham stated that Parliament had gone to some lengths to avoid a procedure which crossed the criminal boundary: with control orders there was no assertion of criminal conduct, only a foundation of suspicion; no identification of any specific criminal offence was provided for; the order made was preventative in purpose, not punitive or retributive; and the obligations imposed had to be no more restrictive than were judged necessary to achieve the preventative object of the order. ${ }^{78}$ In addition, whilst the standard of proof for imposing a control order - reasonable suspicion - is low, notably, this, too, has not been found wanting by the House of Lords.

71 Amnesty International, United Kingdom: Five years on, n. 8 above, p. 16.

72 Liberty, From “War" to Law, n. 66 above.

73 [2007] UKHL 46, [2008] 1 AC 440.

74 [2007] UKHL 47, [2008] 1 AC 449.

75 [2007] UKHL 45, [2008] 1 AC 385.

76 Ibid. para. 108.

77 [2007] UKHL 46, [2008] 1 AC 440.

78 Ibid. para. 24. 
In reference to the procedural protections afforded by the PTA itself, for all control orders there are independent judicial proceedings at an early stage of the process, as per ss. 3(4) and 3(10). ${ }^{79}$ Whenever evidence is dealt with in open court, a controlee is represented by lawyers of their own choosing. In this case, the ECtHR in $A \mathrm{v}$ United Kingdom ${ }^{80}$ said that an individual had been given an effective opportunity to challenge the state's suspicions about them. ${ }^{81}$ If the evidence is too sensitive to be published in open court, then a special advocate is appointed to represent the interests of the suspect. On this issue, the ECtHR in $A$ also said that the special advocate could perform an important role in counterbalancing the lack of full disclosure and the lack of a full, open, adversarial hearing by testing the evidence and putting arguments on behalf of the detainee. ${ }^{82}$ In fact, the court said that it was only where the detention was based solely or to a decisive degree on closed material (or the open material consisted purely of general assertions) that the procedural requirements of the ECHR would not be satisfied. ${ }^{83}$ But when the House of Lords in Secretary of State for the Home Department $\mathrm{v} A F^{84}$ followed this element of the ECtHR's ruling in $A$, it did so with much reluctance. In holding that non-disclosure on the ground of national security of relevant material could not go so far as to deny a controlee knowledge of the essence of the case against him or her, ${ }^{85}$ Lord Hoffman, for example, said: "I do so with very considerable regret, because I think that the decision [in $A$ ] ... was wrong." 86 Academic commentators have expressed dismay about the ruling of the ECtHR, too. English suggests that "despite all the careful safeguards set in place in the SIAC system", the ECtHR "in their wisdom . . . has created an impossibly impractical standard for disclosure . . and dragged the UK courts with it". ${ }^{87}$ Are control orders, therefore, so awful in terms of procedural freedoms - especially when weighed against the obvious public benefits of preventing terrorism? Public protection is one of the reasons why Article 6(1) of the ECHR does not confer an absolute right on an individual to a fair trial.

\section{ARTICLE 3 OF THE ECHR: THE PROHIBITION ON TORTURE AND INHUMAN AND DEGRADING TREATMENT AND PUNISHMENT}

As regards to a control order's possible breach of Article 3 of the ECHR, the previous indefinite provisions under the ATCSA were found not to be in violation of the absolute ban on inhuman and degrading treatment by the ECtHR in $A$. Whilst recognising that the uncertainty and fear of indefinite detention had to have caused the applicants anxiety and distress, and it was probable that the stress had been sufficiently serious and enduring to affect the mental health of some of the applicants, the court said that it could not be said that the applicants had been without any prospect or hope of release. ${ }^{88}$ In particular, they had been able to bring proceedings to challenge the legality of the detention scheme. ${ }^{89}$ Furthermore, each detained applicant had also had at their disposal the remedies available to all prisoners under administrative and civil law to challenge conditions of detention,

79 But the standard upon which a controlee can challenge the imposition of control order before a court is high - see: Walker, Blackstone's Guide, n. 5 above, p.222.

80 (2009) 49 EHRR 29.

81 Ibid. para. 220.

82 Ibid.

83 Ibid.

84 [2009] UKHL 28, [2009] 3 WLR 74.

85 Ibid. para. 59.

86 Ibid. para. 70.

87 R English, “Case comment”, UK Human Rights Blog, 12 June 2009: www.1cor.com/1315/?form_1105.

88 (2009) 49 EHRR 29, para. 130.

89 Ibid. para. 131. 
including any alleged inadequacy of medical treatment. ${ }^{90}$ Control orders are much less of an incursion into individual freedoms than the previous indefinite detention provisions under ATCSA. Since the ECtHR in $A$ held that the latter were not in violation of Article 3 , the same conclusions obviously can be drawn about control orders (subject, of course, to the earlier ruling of the Supreme Court in $A P$ (No 2), ${ }^{91}$ in reference to the possible granting of anonymity to a controlee, to prevent racist reprisals).

\section{ARTICLE 8 OF THE ECHR: THE RIGHT TO PRIVATE AND FAMILY LIFE, HOME AND CORRESPONDENCE}

Unlike Article 3 of the ECHR, which is an absolute right, and therefore not permitting any limitations by the state, Article 8 is a qualified right where the courts apply the principle of proportionality. That is, they must weigh the private right of the controlee - the right to private and family life, home and correspondence, as per Article 8(1) - with the state's objective for infringing the right - in this case national security, as per Article 8(2) - making sure that that the infringement of the private right is in proportion to the state's objective. Reference was made above to the case of Secretary of State for the Home Department $\mathrm{v} A P .^{92}$ Here the applicant, AP, was living in the Midlands, 200 miles away from the rest of his family in London. The Supreme Court did rule that the rights of the applicant were proportionately infringed for the purposes of protecting national security. It is likely therefore that (in most cases, at least) control orders, despite being infringements of Article 8(1) of the ECHR, are necessary in the legitimate interests of the state, as per Article 8(2).

In further consideration of the Article 8 implications of the control order scheme, reference can also be made to the Control Order Review Group (CORG). The creation of this body was recommended by the then independent reviewer of the PTA, Lord Carlile of Berriew QC, in $2008^{93}$ (see more about Lord Carlile in the text below). CORG meets every three months with representation from law enforcement and intelligence agencies "to keep the obligations in every control order under regular and formal review and to facilitate a review of appropriate exit strategies". ${ }^{4}$ Lord Carlile, who believes that the work of CORG is "well-organised and methodical", 95 states that a factor for bringing an order to an end is its impact on the individual's family, especially any children living with them. ${ }^{96}$

\section{OTHER ARGUMENTS SUPPORTING CONTROL ORDERS}

In addition to the judicial safeguards outlined above, as per s. 3 of the PTA, the legislation provides other protections against executive abuse. For example, strict time limits apply to control orders (a non-derogating control order lasts for 12 months, as per s. 2(4), but is renewable); the Home Secretary is obliged to report to Parliament every three months on the operation of the control order powers, as per s. 14(1); the legislation must be renewed

90 (2009) 49 EHRR 29, para. 133.

91 [2010] UKSC 26, [2010] 3 WLR 51.

92 Ibid.

93 Lord Carlile of Berriew QC, Third Report of the Independent Reviewer Pursuant to Section 14(3) of the Prevention of Terrorism Act 2005, 1 February 2008: http://security.homeoffice.gov.uk/news-publications/publicationsearch/prevention-terrorism-act-2005/lord-carlile-third-report.html, para. 47.

94 Home Office, Written Ministerial Statement on Control Orders: 11 June-10 September 2010, 16 September 2010: www.homeoffice.gov.uk/publications/parliamentary-business/written-ministerial-statement/control-orderssep2010-wms/.

95 Lord Carlile of Berriew QC, Fifth Report of the Independent Reviewer Pursuant to Section 14(3) of the Prevention of Terrorism Act 2005, 1 February 2010: www.statewatch.org/news/2010/feb/uk-carlile-5th-report-on-terr-act2005.pdf, para. 121 .

96 Ibid. para. 119. 
annually by Parliament, as per s. 13; and there is an annual review of the legislation by an independent reviewer, as per s. 14(2), a copy of which must be laid before Parliament, as per s. 14(6). In the opinion of the author, therefore, the nature of the scheme does not seem so draconian when these safeguards are taken into account. Indeed, other UK anti-terror initiatives, such as "deprivation of citizenship" orders, as per s. 40 of the British Nationality Act 1981, where some British citizens suspected of terrorism have had their passports confiscated while they were travelling abroad, are arguably far more intrusive of human rights than control orders, ${ }^{97}$ but seem to be overlooked in the desire to attack the control order scheme. One could also compare the control order scheme with other anti-terror initiatives adopted by comparable democracies to the UK such as the USA. For example, in May 2011 America's US House of Representatives passed the National Defense Authorization Act which expands the President's military targeting power. It authorises, with no end date, the targeting of undefined forces "associated" with al-Qaeda and the Taliban and those "substantially supporting" those forces with no connection to the 9/11 attacks or to any armed conflict. Those accused of being part of this undefined group can be detained indefinitely without charge. They are entitled to only minimal review of their detention once a year (and a slightly broader review before a military panel only every three years). They are not entitled to have a lawyer to represent them or to be presented with all the evidence against them. ${ }^{98}$

On the issue of an annual independent review of the PTA, this was undertaken, as stated above, by Lord Carlile of Berriew QC (until February 2011 when he was replaced by David Anderson QC). In his fifth annual report, dated February 2010, Lord Carlile - as in previous reports 99 - believed that the control order system was "necessary"100 and abandoning the regime entirely would have a "damaging effect on national security". ${ }^{101} \mathrm{He}$ says that he has considered whether control orders can or should be replaced by something else, or even re-named, but has been "unable to find, or devise, a suitable alternative". ${ }^{102}$ He concludes, therefore, that there was "no better means of dealing with the serious and continuing risk posed by some individuals". ${ }^{103}$

In informing his conclusions, Lord Carlisle analysed the operation of the control order scheme in 2009. He studied all the current control order cases, looking at the same information about each individual that would have been shown to the Home Secretary. His report finds: "I would have reached the same decision as the Secretary of State in each case in which a control order has been made . .."104 In particular, three of the controlees whose case Lord Carlile examined have been the subject of orders for more than two years. In reference to the terror threat posed by these three individuals, Lord Carlile observes:

There is significant and credible intelligence that [these individuals] continue to present actual or potential, and significant danger to national security and public safety. I agree with the assessment that the control order on each has substantially

97 D Taylor, "British terror suspects banned from returning to UK", The Guardian, 27 January 2011: www.guardian.co.uk/law/2011/jan/27/british-terror-suspects-banned-return.

HRW, "US: House passes drastic detention measures in Defense Bill”, 26 May 2011: www.hrw.org/en/news/2011/05/26/us-house-passes-drastic-detention-measures-defense-bill.

99 Lord Carlile, Third Report, n. 93 above, para. 47.

100 Lord Carlile, Fifth Report, n. 95 above, para. 85.

101 Ibid.

102 Ibid. para. 97.

103 Ibid. para. 85.

104 Ibid. para. 114. 
reduced the present danger that exceptionally they still present despite their having been subject to a control order for a significant period of time. ${ }^{105}$

Control orders have other noted defenders. Importantly, they are supported by the director general of the security service (MI5), Jonathan Evans, on the basis that "terrorist threats can still exist which the criminal justice system cannot reach". ${ }^{106}$ Moreover, the Centre for Social Cohesion (CSC), which is a think-tank specialising in the study of radicalisation and extremism in the UK, also favours the scheme. The CSC argues that control orders are the "best option available" in the fight against terror. ${ }^{107}$ It states that an overstretched security service is dealing with a large number of UK-based al-Qaeda sympathisers. Rather than weakening the current national security structure, politicians should be strengthening the state's ability to reduce the terrorist threat. ${ }^{108}$

One of the concerns raised about the control order scheme is the significant financial cost of the measures, especially when the numbers subject to control orders are very small. At the time of writing, there is considerable unease amongst public sector employees because of the Coalition government's intention to cut spending in order to reduce the annual public sector financial deficit. To this end, many civil servants and government ministers have been lobbying the Treasury to avoid large grant reductions to their departments, very often citing concerns about their department's continued ability to fight international terrorism. One such department concerned about cost reductions is the Ministry of Defence. Recently Air Marshal Timo Anderson, director general of the Military Aviation Authority, addressed MPs in a private talk, outlining the effects public sector spending cuts would have on state objectives, such as preventing terrorism. The RAF is expected to lose significant numbers of jet fighters in spending cuts of up to 10 per cent over four years. In response, Air Marshal Anderson said that the UK would be "unable to respond effectively to a 9/11-style terrorist attack from the air". ${ }^{109}$ Of course, deploying fighter jets to intercept suspected planes not responding to calls from air traffic controllers is another anti-terror initiative by the state. But is it not the case that the ongoing costs of the control order scheme pale into insignificance compared to the possible retention of RAF fighter jets as another "prevent" measure?

\section{JUSTIFYING CONTROL ORDERS ON THE BASIS OF ARTICLE 2 OF THE ECHR: THE RIGHT TO LIFE}

There is little doubt that the UK is at serious risk of terrorism, especially from Islamic terror groups which engage in acts of atrocity, such as suicide violence, with maximum effect. For example, in 2005, the 7 July suicide attacks on the London transport network killed 52 people and injured over $700 ;{ }^{110}$ again in 2005, were the four failed suicide attacks in London a fortnight later on 21 July; 111 in 2006 , there was the "airline bomb plot", a plot to blow up

105 Lord Carlile, Fifth Report, n. 95 above, para. 43.

106 J Evans, "The threat to national security", 16 September 2010: www.mi5.gov.uk/output/the-threat-tonational-security.html, para. 11.

107 R Simcox, Control Orders: Strengthening national security, Centre for Social Cohesion, June 2010: www.socialcohesion.co.uk/files/1284130287_1.pdf, p. 8.

108 Ibid.

109 BBC News, “Cuts endanger UK, RAF's Timo Anderson warns”, 13 October 2010: www.bbc.co.uk/news/ukpolitics-11529330.

110 BBC News, “London attacks", 8 July 2005: http://news.bbc.co.uk/1/hi/in_depth/uk/2005/ london_explosions/default.stm.

111 BBC News, "21 July attacks: arrests and charges", 27 January 2006: http://news.bbc.co.uk/1/hi/uk/ 4732361.stm. 
planes, flying from London to America, with home-made explosive liquids; ${ }^{112}$ and in 2007 there were car-bomb attacks in London and at Glasgow Airport. ${ }^{113}$ In 2009, there was a coordinated terror arrest of 11 men in the north-west of England (Operation Pathway) who were suspected of planning to blow up the Arndale Shopping Centre in Manchester. ${ }^{114}$ (Two of these suspects have since been named as conspirators in a plot to bomb the New York subway.) ${ }^{115}$ Recently, an explosive device was found on a US-bound cargo plane at East Midlands Airport which could have been detonated over the UK. ${ }^{116}$ There are also fears that London will be the site of a future terror attack because it is the host city of the Olympic games in 2012.117 Indeed, it has recently been reported that Islamic terror groups are intent on acquiring chemical, biological, radiological and nuclear (CBRN) weapons for use against civilian targets. ${ }^{118}$

These atrocities point to a continuation of terror threats to the UK in the name of fundamentalist Islam. In fact, the director general of MI5, Jonathan Evans, has recently said that the UK continues to face a "serious risk of a lethal attack taking place" from al-Qaedarelated terrorism, ${ }^{119}$ which is obviously compounded by the recent killing of the leader of al-Qaeda, Osama bin Laden, by US special forces in Pakistan. ${ }^{120}$ In the author's opinion, this justifies the retention of the control order scheme as a measure to prevent further atrocity, especially by reference to the rights of individuals to be protected from terrorist violence. This justification may sit uneasily with liberals, for example, but the trumping of the rights of terror detainees by the rights of potential victims is well recognised, ${ }^{121}$ especially at the heart of government. For example, in October 2008 when the state was wishing to increase the period of pre-charge detention of terror suspects from 28 days to 42 days, the then Home Secretary, Jacqui Smith, said:

The provisions in this Bill have always been about protecting the British people - protecting them from the serious threat that we face from terrorism. My approach has always been to strike the right balance between protecting national security and safeguarding the liberty of the individual . . But, for me, there is no greater individual liberty than the liberty of individuals not to be blown up on British streets or in British skies. (italics added) ${ }^{122}$

112 BBC News, "Three guilty of airline bomb plot”, 7 September 2009: http://news.bbc.co.uk/1/hi/uk/ 8242238.stm.

113 BBC News, "Bomb plot doctor jailed for life", 17 December 2008: http://news.bbc.co.uk/1/hi/uk/ 7786884.stm.

114 M Hughes and L Smith, "Suspects in Manchester bomb plot wanted in us over subway attack", The Independent, 8 July 2010: www.independent.co.uk/news/uk/crime/suspects-in-manchester-bomb-plot-wanted-in-us-oversubway-attack-2021221.html.

115 Ibid.

116 BBC News, "Air freight from Yemen and Somalia banned", 1 November 2010: http://www.bbc.co.uk/news/ uk-11669636.

117 ANI, "Fears of terror threat to London Olympics as 10 Extremists Walk Free on UK streets", 13 June 2011: www.dailyindia.com/show/445002.php.

118 D Gardham, "Nuclear terror risk to Britain from Al-Qaeda", The Telegraph, 22 March 2010: www.telegraph.co.uk/news/uknews/terrorism-in-the-uk/7500719/Nuclear-terror-risk-to-Britain-from-alQaeda.html.

119 Evans, "The threat", n. 106 above.

120 R Booth, "Osama bin Laden death prompts worldwide security alert", The Guardian, 2 May 2011: www.guardian.co.uk/world/2011/may/02/osama-bin-laden-death-security-alert.

121 See, for example, D McKeever, "The Human Rights Act and anti-terrorism in the UK: one great leap forward by Parliament, but are the courts able to slow the steady retreat that has followed?” (2010) PL 110, pp. 136-7.

122 J Smith: www.publications.parliament.uk/pa/cm200708/cmhansrd/cm081013/debtext/81013-0017.htm. 
The author of this article believes that the views of the then Home Secretary, Jacqui Smith, are particularly significant, especially the references to the liberty of individuals not to be blown up. Recently, the inquest into the deaths of the 52 people who died in the coordinated suicide attacks in London on 7 July 2005 was held. As per s. 11(5)(ii) of the Coroner's Act 1988 an inquest must decide how, when and where a deceased came by their death. It was reported that one of the victims, a 41-year-old tax inspector who was married with two children, had been standing opposite Shehzad Tanweer, one of the 7 July bombers. He was blown out of the carriage and his body was found face down on the track. One witness said this victim's clothes had been blown off by the force of the blast. ${ }^{123}$ Reading the accounts about those who died in the $7 / 7$ attacks, one cannot fail to sympathise with strategies, such as control orders, to prevent atrocities such as these, perhaps justified on the basis of the more important right to life of those who died.

Assuming there is a right to life argument justifying the imposition of control orders, perhaps this could be made out by reference to Article 2 of the ECHR? The state is, of course, not directly responsible for the deaths of UK citizens in atrocities such as $7 / 7$, so the issue of the "negative" right not to be arbitrarily killed by the state contained in Article 2(2) of the ECHR - the situations in which the use of lethal force by state agents may be lawful - is not relevant. However, Article 2(1) of the ECHR, the "positive" or "substantive" obligation imposed on the state, may still be applicable. This states: "Everyone's right to life shall be protected by law." Is there not a "positive" duty on the UK authorities to avert a terror threat by imposing controls on a suspected terrorist, in pursuit of its more important obligation to protect British citizens from atrocity? Indeed, in the light of the recent discovery at East Midlands Airport of a "viable" explosive device on board a US-bound cargo plane, The Telegraph has opined:

Our security must always come first. The most fundamental human right is the right to walk down the streets without threat of harm ... [The] first duty of any government is to protect the safety of its citizens. ${ }^{124}$

The newspaper then goes on to support the control order scheme as a justifiable measure in maintaining security, otherwise "the only feasible alternative is to leave such people at liberty to plot further acts of terrorism". ${ }^{25}$

In considering the state's "positive" duty to protect life, and whether this may legitimise the control order scheme, first, there is no general obligation on the UK authorities to avert death: $\mathrm{R}$ (Gentle) v Prime Minister. ${ }^{126}$ However, the positive obligation does oblige the UK to deter the taking of life in broad terms. For example, the ECtHR in Osman $\mathrm{v}$ United Kingdom ${ }^{127}$ said:

It is common ground that the State's obligation . . extends beyond its primary duty to secure the right to life by putting in place effective criminal law provisions to deter the commission of offences against the person backed up by lawenforcement machinery for the prevention, suppression and sanctioning of breaches of such provisions. ${ }^{128}$

\footnotetext{
123 Smith, n. 122 above.

124 "Editorial: Our security must always come first", The Telegraph, 31 October 2010: www.telegraph.co.uk/news/ uknews/terrorism-in-the-uk/8099274/Our-security-must-always-come-first.html.

125 Ibid.

126 [2008] UKHL 20, [2008] 1 AC 1356.

127 (2000) 29 EHRR 245.

128 Ibid. para. 115.
} 
Of course, control orders are measures designed to deter the taking of human life, thus perhaps satisfying this element of the positive obligation. But because of the potentially serious human rights implications of obligations imposed on a controlee, the author suspects that the substantive duty contained in Article 2(1) does perhaps require a greater justification for the scheme. Indeed, the ECtHR in Osman did say that particular circumstances must have arisen before a state would be obliged to act to avert the loss of life:

Where there is an allegation that the authorities have violated their positive obligation to protect the right to life . . . it must be established . . . that the authorities knew or ought to have known at the time of the existence of a real and immediate risk to the life of an identified individual or individuals from the criminal acts of a third party ... 129

To utilise the state's positive duty under Article 2(1) as a basis for legitimising control orders, there would therefore have to be more than a general risk to individuals from terrorism, but a specific threat to identifiable victims - and then this would have to constitute a real and immediate risk. The Osman principles have been applied in UK law by the House of Lords in, for example, Van Colle v Chief Constable of the Hertfordshire Police. ${ }^{130}$ In Van Colle, the deceased, Giles Van Colle, was shot dead by a former employee, Daniel Brougham, just days before he was due to give evidence for the prosecution at Brougham's trial for theft. The House of Lords ruled that the Hertfordshire police were not in breach of Article 2(1) in failing to protect the life of Mr Van Colle. In reference to Osman's requirement that a real and immediate risk to life should exist, Lord Brown said:

The test set by the European Court of Human Rights in Osman . . . is clearly a stringent one which will not be easily satisfied ... It is indeed some indication of the stringency of the test that even on the comparatively extreme facts of Osman itself . . . the Strasbourg court found it not to be satisfied. ${ }^{131}$

Of course, therefore, reaching the threshold for imposing liability on the state for failing to protect life will be difficult. But not insurmountable, and in fact the positive duty to protect the lives of the community in general from possible violations by terrorists was one of the concerns expressed by the ECtHR in McCann v United Kingdom. ${ }^{132}$ There the Special Air Service (SAS) shot dead three suspected Irish Republican Army (IRA) terrorists in Gibraltar who were planning to detonate a car bomb. The UK authorities had followed the IRA bombers from Malaga in Spain and allowed them not only to cross the Spanish border into Gibraltar, but to prepare for the attack at the site of the proposed bombing. Although the police had knowingly done all of these things because of the belief that they had insufficient evidence to charge the suspects with a crime, the ECtHR said that they had still exposed the local population to possible danger:

It may be questioned why the three suspects were not arrested at the border immediately on their arrival ... and why the decision was taken not to prevent them from entering ... if they were believed to be on a bombing mission. Having had advance warning of the terrorists' intentions it would certainly have been possible for the authorities to have mounted an arrest operation. The danger to the population of Gibraltar - which is at the heart of the Government's submissions - in not preventing their entry must be considered ... The decision

129 (2000) 29 EHRR 245, para. 116.

130 [2008] UKHL 50, [2009] 1 AC 225.

131 Ibid. para. 115.

132 (1995) 21 EHRR 97. 
not to stop the suspects from entering Gibraltar is thus a relevant factor to take into account. ${ }^{133}$

Assuming that there would have to be more than a general risk to individuals from terrorism, but a threat to identifiable victims, which then would have to constitute a real and immediate risk, is it not the case that the evidence required by the Home Secretary to justify the imposition of a control order largely suggests this to be so? For example, s. 2(1) of the PTA only allows the Secretary of State to make a control order against an individual if $\mathrm{s} / \mathrm{he}$ (a) has reasonable grounds for suspecting that the individual is or has been involved in terrorism-related activity; and (b) considers that it is necessary, for purposes connected with protecting members of the public from a risk of terrorism.

If, however, s. 2(1)(b) of the PTA is not sufficiently exacting to warrant the imposition of a control order under Article 2(1) of the ECHR - that is, a risk of terrorism was too broad to encompass knowledge of a real and immediate risk to the life of an identified individual or individuals (or the standard of proof was too low, it being only a reasonable suspicion on the part of the minister) - the author believes that it should be. The threat, and manner of acts of terrorism over the past 10 years surely warrant such an interpretation under, for example, s. 3(1) of the HRA - the courts' obligation to interpret legislation, so far as it is possible to do so, in line with ECHR rights? Assuming the state had a duty to impose a control order on the basis of its positive obligation to protect life, this would not be enough, however: it must only act reasonably in averting death. For example, the ECtHR in Osman also said:

[The positive] obligation must be interpreted in a way which does not impose an impossible or disproportionate burden on the authorities. Accordingly, not every claimed risk to life can entail for the authorities a Convention requirement to take ... measures to prevent that risk from materialising. ${ }^{134}$

The true meaning of this substantive principle is arguably not to impose excessive obligations on the state in fulfilling its duties to prevent death. But could it also conceivably be interpreted as condoning control orders if this could be characterised as "reasonable" when, for example, the recognised alternative to the scheme - the 24-hour surveillance of controlees - is generally accepted as too expensive? It is estimated that teams of up to 30 trained observers would be required to watch one suspect around the clock. ${ }^{135}$ In addition, are the measures also not reasonable when weighed against the hundreds who died and were injured in the $7 / 7$ atrocities, and the subsequent threats to life since then, such as the planned Islamist bombing of Manchester's Arndale Shopping Centre in 2009?

This alleged plot to detonate a terrorist bomb in Manchester in 2009 is particularly significant. The suspected conspirators included Abid Naseer who was named as a potential suspect in the bomb plot to target the New York subway (see above). He fought his deportation from the UK to Pakistan before the SIAC: Naseer, Khan, and Ur Rehman et al. v Secretary of State for the Home Department. ${ }^{136}$ One of the grounds for fighting his deportation was the likelihood that he would be tortured upon his return to Pakistan. Article 3(1) of the United Nations Convention Against Torture (UNCAT), which the UK has ratified, states:

No State Party shall expel, return ... or extradite a person to another State where there are substantial grounds for believing that he would be in danger of being subjected to torture.

133 (1995) 21 EHRR 97, para. 203.

134 (1995) 21 EHRR 97.

135 BBC News, “Control orders: the eight British suspects”, 24 January 2011: www.bbc.co.uk/news/uk-12269236.

136 Appeal no: SC/77/80/81/82/83/09. 
In international law, this rule, which is supported by the jurisprudence of the ECtHR and therefore directly applicable in UK law, ${ }^{137}$ is referred to as the principle of "nonrefoulement". In his "open" judgment, Mitting J said that Naseer was "an Al Qaeda operative who posed and still poses a serious threat to the national security of the United Kingdom" and that "it was conducive to the public good that he should be deported".138 However, the judge did not order his return because:

Despite the restoration of a democratically elected Parliament and government, after eight years of military rule, Pakistan remains a state dominated by its military and intelligence agencies. There is a long and well-documented history of disappearances, illegal detention and of the torture and ill-treatment of those detained, usually to produce information, a confession or compliance ... Anyone, such as Naseer, suspected of belonging to [al-Qaida] would be at risk at the hands of the [Pakistani Security Services]. Legal controls are inadequate. ${ }^{139}$

Tellingly, therefore, Abid Naseer was not deported from the UK because, in all likelihood, his rights under the UNCAT would be infringed upon return to Pakistan. What therefore can the UK government reasonably be expected to do in this instance? Surely, it must not permit Abid Naseer (and others like him) unfettered liberty when an independent court has labelled him as an al-Qaida operative and a threat to national security (notwithstanding the state has insufficient evidence to convict him of a crime)? As Walker observes: "The meagre number of control orders is not for want of customers." 140 An article in The Telegraph has recently asked: "Control orders are not very British - but what's the alternative?" It continues:

How would Mr Cameron [the Prime Minister] . . . or Nick Clegg, the Liberal Democrat Leader, explain to the families of those killed that the terrorist responsible had been under suspicion but the restrictions on his movements were removed because they were, you know, not the sort of thing we do in Britain. ${ }^{141}$

This article justifies the continuation of control orders primarily on the state's duty to protect life under Article 2(1) of the ECHR. Ironically, the scheme also honours the UK's domestic, European and international legal duties in not exposing a foreign terror suspect to a threat of torture (assuming, of course, a receiving state has not assured the UK that a deportee will be well-treated upon return). If the author has not made the case that control orders demand, for example, an Article 2(1) compliant interpretation of the legislation as per s. 3(1) of the HRA, or at the very least serious consideration, where does the debate proceed from here?

Earlier it was stated that upon forming a Coalition government with the Liberal Democrats in mid-2010, the Conservative Home Secretary, Theresa May, announced a review of Labour's many counter-terrorism measures, one of which was the control order scheme. ${ }^{142}$ This review, which considered whether the measures should either be retained,

137 See, for example, Chahal v United Kingdom (1996) 23 EHRR 413.

138 Appeal no: SC/77/80/81/82/83/09, at para. 16.

139 Appeal no: SC/77/80/81/82/83/09, at para. 16

140 Walker, "The threat of terrorism", n. 49 above, p. 5.

141 P Johnston, "Control orders are not very British - but what's the alternative?", The Telegraph, 1 November 2010: www.telegraph.co.uk/comment/columnists/philipjohnston/8103215/Control-orders-are-not-veryBritish-but-whats-the-alternative.html.

142 Home Office, Rapid Review, n. 6 above. 
removed, reformed or replaced, has now been completed and published. ${ }^{143}$ It accepted that for the foreseeable future there was very likely to be a small number of people who pose an immediate and significant terrorist threat but who can neither be prosecuted nor deported. ${ }^{144}$ And while increased surveillance could form an important part of any arrangements replacing control orders, surveillance alone could not mitigate risk to the level of a control regime. ${ }^{145}$ Moreover, the costs of surveillance exceed by a considerable margin the costs of control orders. ${ }^{146}$ The review therefore recognised that an approach that introduced more precisely focused and targeted restrictions than the current control order scheme would mitigate risk while increasing civil liberties. ${ }^{147}$

In discussing the more precisely focused and targeted restrictions, which are going to be called Terrorism Prevention and Investigation Measures (TPIMs), the review acknowledged that limits on communications, association and movement will be required for the new regime to be effective. ${ }^{148}$ But there will be greater freedom of communication and association than the existing arrangements, placing only limited restrictions on communications, including use of the internet, and on the freedom to associate. ${ }^{149}$ Instead of curfews there will be an overnight residence requirement with some additional flexibilities (for example, in relation to overnight stays outside the residence). ${ }^{150}$ Additional resources will be made available to complement the new regime. ${ }^{151}$ There are also proposals to reform the Home Secretary's suspicion about a controlee's involvement in terrorismrelated activity. Currently, a control order cannot be issued under s. 2(1) of the PTA 2005 unless the minister has reasonable grounds for the suspicion that a controlee is involved in terrorism. The review says that the threshold is to be raised to "reasonable belief". ${ }^{152}$

The report finds that the new system is neither a long-term nor an adequate alternative to prosecution, which remains the priority. These measures will be time limited to two years to emphasise that they are a short-term expedient not a long-term solution. They may be reimposed after two years only where there is new material to demonstrate that the person concerned poses a continued threat. ${ }^{153}$ Interestingly, the report concludes that there may be exceptional circumstances where the government will seek parliamentary approval for additional restrictive measures. In the event of a very serious terrorist risk that cannot be managed by any other means, more stringent measures may be required. Such measures will include curfews and further restrictions on communications, association and movement. But they will only be allowed if the Secretary of State is satisfied on the balance of probabilities (an even higher threshold than reasonable belief) that the person is or has been involved in terrorism. ${ }^{154}$ More information about these measures has been forthcoming with the publication of the Terrorism Prevention and Investigation Measures Bill 2011,

143 HM Government, Review of Counter-Terrorism and Security Powers: Review Findings and Recommendations, CM 8004, January 2011: www.homeoffice.gov.uk/publications/counter-terrorism/review-of-ct-security-powers/reviewfindings-and-rec?view $=$ Binary.

144 Ibid. p. 37.

145 Ibid.

146 Ibid.

147 Ibid. p. 39.

148 Ibid. p. 42.

149 Ibid.

150 Ibid.

151 Ibid.

152 Ibid. p. 40.

153 Ibid. pp. 41-2.

154 Ibid. p. 43. 
which, at the time of writing, is currently being debated by Parliament. Notably, according to cl. 5(1), the maximum period of a TPIM in the first instance is now only one year rather than two years, though it can be extended for a further year, but only once, cl. 5(2). But a TPIM can be extended after the maximum two-year period if there is a reasonable belief that the individual has been engaged in terrorist activity during the currency of the order, as per cl. 3. Also, the government has since indicated that a person's relocation to another part of the country without that person's consent is not going to be permitted, since the only conditions that can be imposed on a person are found in Schedule 1 of the Bill. ${ }^{155}$ TPIMs are not intended for implementation before 2012 at the earliest because MI5 needs to recruit and train more surveillance officers to cope with the change. ${ }^{156}$

Some of these proposals by the review have been recommended previously. Timelimiting a control order is nothing new. For example, Walker had suggested that there should be a maximum time limit of 12 months without renewal. 157 Then it would turn a control order into either a provisional charge detention or a provisional deportation detention "either way the authorities would know they have to act decisively by collecting further evidence and not rely on control orders for what one Minister . . called 'an indefinite, limited period". 158 A maximum term for a control order was also supported by, for example, the JCHR in its 2009 report on the PTA. ${ }^{159}$ But here the government is recommending limiting TPIMs to two years, rather than one year, and allowing them to continue after two years if they are necessary. However, arguments in favour of relaxing the conditions and the raising of the standard of proof from reasonable suspicion to reasonable belief, have been less common in academic and legal circles, in the author's opinion.

\section{Conclusion}

Control orders are seemingly an anathema to traditional British standards of decency and fairness. Since the HRA came into force in October 2000, convention rights of the ECHR, as per s. 1 of the statute, have been incorporated into domestic law. So, rights such as Article 3, freedom from torture and other forms of ill-treatment, Article 5, the right to liberty, Article 6, the right to a fair trial, and Article 8, the right to privacy, are all directly enforceable in UK law. Arguably, in the issuing of a control order, these Articles have all been infringed for the purposes of pursuing the state's aim of preventing terrorism. However, the courts have said that some obligations imposed on a controlee, such as curfew hours not exceeding 16 hours per day, are lawful. They have also upheld control orders where the essence of a case against an individual is revealed so that the detainee can give meaningful instructions to their special advocate before SIAC. They have also implied that the imposition of a control order, with the obvious anxiety and stress that follows from this, is, nonetheless, not ill-treatment for the purposes of Article 3 (subject, of course, to the ruling of the Supreme Court in $A P$ (No 2)).

But what seems to have been lost in the debates about the legality of the control order scheme are the (overriding?) rights to life of ordinary citizens. And, when considering the

155 Home Office, “Terrorism Prevention and Investigation Measures Bill”, 23 May 2011: www.homeoffice.gov.uk/publications/about-us/legislation/tpim-bill/.

156 D Gardham, "MI5 on recruitment drive to cope with new control orders", The Telegraph, 9 March 2011: www.telegraph.co.uk/news/uknews/terrorism-in-the-uk/8371804/MI5-on-recruitment-drive-to-cope-withnew-control-orders.html.

157 Walker, "The threat of terrorism”, n. 49 above, p. 16.

158 C Walker, "Terrorism: Prevention of Terrorism Act 2005 ss. 2 and 3 - non-derogating control order - whether 'deprivation of liberty' under the European Convention on Human Rights Article 5" (2008) Crim LR 487, p. 502.

159 JCHR 2009, n. 31 above, para. 2. 
risks posed by individual suspects (which have been verified by the former independent reviewer of the PTA, Lord Carlile, during the currency of the legislation, and the courts such as the SIAC in Naseer), surely the rights to life of the many must prevail over the freedoms of the few, the very small number of controlees?

Article 2(1) of the ECHR imposes a positive obligation on the state to protect life. The author has attempted to construct a right to life argument justifying the retention of the control order scheme. If he has been unsuccessful with this, then it must be remembered that debates about the threats certain people pose to society have happened in other contexts: for example, the Mental Health Act 2007 amends significantly the provisions of the Mental Health Act 1983 and, in particular, reforms s. 3(2) of the latter Act, the so-called "treatability requirement", which used to restrict the detention for treatment of individuals with a psychopathic disorder. ${ }^{160}$ Indeed, if we wish to remain faithful to our international obligations in respect of Article 3(1) of the UNCAT, in circumstances where "diplomatic assurances" do not exist, how else are we to deal reasonably with foreign suspects who, without reservation, are determined to commit further acts of atrocity? And there are suspects who cannot be deported because of their British nationality status. It must be remembered, therefore, that, in defending the current control order scheme, the author is not calling for an extension to existing terror laws such as the reintroduction of the indefinite detention provisions, as per the ATCSA.

If the conclusion to be drawn from this piece was simply based on the weight to be attached to both sides of the control order argument, the balance probably falls on the side of those who oppose the measures (assuming, of course, the author has been unable to construct a credible argument in reference to Article 2(1) of the ECHR). But the aim here has not been to present a conclusion merely based on the number of words that the author could find to support or reject the continuation of the scheme. The intention has been to challenge the negative opinions expressed about the measures which appear to have taken centre stage in recent years, where the rights to life, for example, of ordinary individuals have seemingly been overlooked. The aim of this article has therefore been to present a genuine defence of control orders on the basis of the state's obligation to protect life. It is hoped that it has achieved this objective. If not, the new TPIMs may be a useful compromise, since duties imposed on a suspect are apparently going to be relaxed: the replacement of curfews with overnight residency requirements, thus reducing the maximum time a person is obliged to domicile at a particular residence, being an obvious example. But TPIMs are not a revolution in terms of individual freedoms. Proceedings are still going to be modelled on the SIAC system, as per Schedule 4 of the published Bill, which, for some individuals, means primarily, if not completely, closed hearings. And yes, while the threshold for imposing a control order is to be raised from reasonable suspicion to reasonable belief, as per cl. 3(1), this is not going to make much difference in practice. For example, Lord Carlile, the former independent reviewer of the PTA, in his latest, and final, sixth report, has said that the control orders currently in existence would have been granted on this standard of proof in any event (and "in most cases by some distance the full civil standard

160 The concern about the risk some individuals suffering from a psychopathic disorder posed to society, such as Christopher Clunis, Michael Stone, Anthony Hardy and others, is an underlying theme of the Mental Health Act 2007. For example, s. 1 amended the previous definition of mental disorder in s. 1 of the Mental Health Act 1983, broadening the scope of the state's compulsory powers over individuals suffering from a mental disorder; and s. 32 amends s. 17 of the Mental Health Act 1983, introducing for the first time compulsory treatment powers in the community ("supervised community treatment"). 
of balance of probabilities"). ${ }^{161}$ Moreover, TPIMs will not be subject to an annual renewal by Parliament, ${ }^{162}$ which is the case with the existing control order regime. As much as the present Coalition government has portrayed TPIMs as a significant reform of the existing regime, other commentators have, instead, likened them to control orders in all but name. ${ }^{163}$ It is for this reason that they are arguably an acceptable substitute for control orders since the important obligation of the state to protect the public from terrorism still seems to be the determining factor.

161 Lord Carlile of Berriew QC, Sixth Report of the Independent Reviewer Pursuant to Section 14(3) of the Prevention of Terrorism Act 2005, 3 February 2011: www.homeoffice.gov.uk/publications/counter-terrorism/independentreviews/lord-carlile-sixth-report?view=Binary, p. 15.

162 House of Commons Library, Terrorism Prevention and Investigation Measures Bill: Bill 193 of 2010-11, Research Paper 11-46, 31 May 2011: www.parliament.uk/briefing-papers/RP11-46.pdf, p. 1.

163 J Kirkup and D Gardham, "Control orders to remain 'in all but name", The Telegraph, 7 January 2001: www.telegraph.co.uk/news/politics/8246756/Control-orders-to-remain-in-all-but-name.html. This is one of the reasons why they have been criticised by interested groups such as Amnesty International and HRW: Amnesty International, "UK counter-terrorism review: some progress but concerns about right to fair trial remain says Amnesty”, 26 January 2011: http://www.amnesty.org.uk/news_details.asp?NewsID=19203; and HRW, "UK: proposed counterterrorism reforms fall short", 11 February 2011: www.hrw.org/en/news/ 2011/02/11/uk-proposed-counterterrorism-reforms-fall-short. 
